\title{
Impacts of change management on risk and cost management of a construction projects
}

\author{
Mohamed Ibrahim Khalifa Halou ${ }^{a}$, Razali Samin a and Mushtaq Ahmad ${ }^{\text {b* }}$
}

${ }^{a}$ Faculty of Engineering Management, University Putra Malaysia (UPM), Malaysia ${ }^{b}$ Department of Civil Engineering, Tenaga Nasional Univeristy Malaysia (Uniten), Malaysia

CH R O I C L E A B S TRACT

Article history:

Received: October 22018

Received in revised format: November 192018

Accepted: January 122019

Available online:

January 142019

Keywords:

Construction Projects

Change Management

Cost Management

Risk Management

\begin{abstract}
Construction projects are always problematic and difficult to manage in certain stages. Management in construction industry has been characterized as being weak, insufficient, nebulous, backward and slow to react against changing conditions. This study aims to identify risk and cost managed in the change management of the construction projects. Quantitative study is organized and questionnaire as an instrument is used to collect the information from the construction experts in Klang Valley, Malaysia. Random sampling techniques is used to collect the data, 105 questionnaires are distributed and 90 ones are returned. The correlation analysis shows significant relationship between cost, risk and change management. The reliability test indicates satisfactory result to continue the questionnaire where Cronbach coefficient alpha value exceeds the level of 0.70 . The study finds that design changes, client and contractor related changes are mostly occurred in change management of construction projects. Tendering on the basis of an incomplete design, which then changes during the course of the construction has been found as the key reason of the changes. Through a paper based exercise, site memorandums (SM), quoted rates (QR), variation orders (VO) and monthly payment certificates (MPC) are the activities managed by the engineers. Proper planning is the most leading change management in the risk management. Implementation of risk management was found the applied risk management in practice to hindrances. Since this is very vast debated subject, the study has recommended further investigation to include consultant firms for better understanding of the design changes leading to the cost and risk associated.
\end{abstract}

(C) 2019 by the authors; licensee Growing Science, Canada.

\section{Introduction}

Managing a construction project is difficult because at the initial stage of a project, the information required to plan and design the project accurately is insufficient to make decisions (Long et al., 2004; Zhao et al., 2009). According to Winch (2010) management of construction projects is a problem of information, or rather, a problem in the lack of information required for decision making. As information, such as the ground conditions, becomes available during the construction phase of the project, it can lead to various changes. Any construction process can be divided into four main phases: program/ or initial idea presented by the client, design (experts involved to design the project according to the idea of the client), procurement (client shortlist the contractors to hire for the project) and production (contractor executes the project followed the client protocol/project * Corresponding author.

E-mail address: ma_5099@yahoo.com (M. Ahmad) 
specification). Traditionally, a construction process is sequential; many actors are involved only in some project phases and focus on their own part of work rather than on the whole project. By the involvement of many stakeholders there is a high possibility of changes occurred in the construction period.

Ibbs et al. (2003) identified several reasons of construction changes which are design errors or omissions, design variations, unforeseen site conditions and uncertainty due to vagueness in the original scope. During a construction project there may be quite a number of these changes. No matter the size of the change, each alteration to the works has a cost, time and risk implication. Due to tight time constraints on most projects, every change requires quick, robust decision making, to prevent any delay in the project, which therefore results in changes not being comprehensively evaluated. Decisions are often made on intuition or experience, without an assessment of the risks involved or the influence on the cost of the project and without applying well-known project management techniques. There are many examples of construction projects where occurred risks have led to significant deviations in the project performance in terms of time, cost and quality. According to a report that investigates more than 3000 quality problems, the cost for poor quality can amount to $20 \%$ of the total cost (Osipova, 2008). Serrador and Turner (2015) found the changes increase costs too. Change management as it is commonly applied in practice, focuses on managing changes in a reactive way. Proactive change management is seldom implemented (Serrador \& Turner, 2015).

Management in construction industry has been characterized as being weak, insufficient, nebulous, backward and slow to react to changing conditions. Nevertheless, in the overall picture, the construction industry is at or near the top in the annual rate of business failures and resulting liabilities (Clough \& Sears, 1986). The problem of applying an effective change management in the construction industries is found to be slow due to the reason of construction project uniqueness; construction projects involve many skills largely non-repetitive in nature, weather conditions, location, transportation and labor that are more or less beyond the contractor's control, construction is risky business and future cannot be forecasted (Motawa et al., 2007; Hao et al., 2008). Therefore, it is important to understand the change management in construction is being applied. The impact of change management on the construction project plays an important role for the success of any business. The aim of the study is to identify the most commonly occurring changes in the construction leading to the reasons, risk association with cost management practicing which are the key focus of this study.

\section{Literature review}

\subsection{Change Management}

Project change can be defined as any event that alters the projects' original scope, execution time or the cost of the works. Improper management of the project's changes could have an immense financial impact which may lead to project cost overruns or even claims and legal disputes (Cunningham, 2017). During the construction phase of a project, change affects every aspect of productivity, the planned schedules and deadlines, work methodology, resource procurement, as well as the budget, and thus it could result in the project objectives not being achieved. The purpose of project change management, therefore, is to insure that changes are carefully reviewed and their impact is properly assessed in order to ensure the success of the project (Radujkovic \& Sjekavica, 2017). There are various methods and models that could be used to manage uncertainty in a project. Risk management, which focuses on identification, analysis and mitigation of risks, is an example of such method. Invariably, any construction project will experience change, and change is coupled with uncertainty. It is also important to note that change and quality cannot be dealt with separately; both affect the project's performance and customer satisfaction (Mišić \& Radujković, 2015). Project managers often use contingencies and construction buffers as the only mechanism for dealing with unexpected change. By fully understanding the implications of the change, project managers are able to manage it more effectively (Yalegama et al., 2016). Change can be categorized into two 
groups, intended and unintended changes. Unintended changes occur without the intervention of managerial actions and are in most cases the result of low quality work, poor work conditions, external scope changes or even upstream hidden changes. Managerial changes are those changes that are assessed, approved and implemented by the project manager (Bakhary et al., 2015). Change could also result in rework, reschedule with the physical manifestation of a design, and thus rework usually entails the demolition or modification of existing structures. Change may have a greater impact on the works than rework (Hanna et al., 2015). Some previous studies concluded most common changes occurred in construction projects are design related change followed by safety management, contract between client and contractors are some mostly occurred changes in the construction (Ahmad et al., 2018; Hanna, 2013; Ibbs et al., 2003; Mišić \& Radujković, 2015).

\subsection{Risk Management}

The risk in the construction project occurred may be due to internal unidentified factors or due to external nature to affect the project on different ways. In the construction field, smaller to larger possibility of happening any type of risk cannot be avoided. The understanding of risk management is essential and in this section risk is grouped based on the occurrence nature and working condition. Murie (2007) divided the risk management occurrence into technical risk and human errors risk. Risk is the function of probability and its impact. That is why it is not always easy to evaluate, as the probabilities and consequences of any particular occurrence cannot be measured accurately. They can only be estimated by statistical analysis, experience and judgment or other methods that would be discussed later (Butt et al., 2016). Risk and uncertainty both deal with a lack of knowledge of a future event, but risk incorporates the probability of such an occurrence, as well as an estimated impact. Proper planning is the first step in risk management (Ahmad et al., 2018). This is where a strategy for the risk management of the whole project is determined and set up in such a way that it can be applied throughout the lifecycle of the project. Risk identification, risk analysis, risk response and risk monitor are the key pillars of risk lifecycle and followed properly in most of the projects. There is interdependency between risk management and change management (Williams, 1999). Every risk management strategy might result in changes to the project which, again, could result in additional risk. They go hand in hand and thus certain companies integrate them into one methodology. Changes that are not managed result in more time and money being required for risk management, which then would be more like crisis management (Sanchez et al., 2009; Lee et al., 2005).

\section{Methodology}

Questionnaire based is used for primary data collection in this study from the experts. The purpose of the using questionnaire survey is because in the past several researchers used such technique by conducting survey among experts. Questionnaire of this study consists several parts including demographic information, common changes occurred in construction followed with reason of change, risk management, cost management, etc. Close ended questionnaire with Likert scale 5 where $1=$ strongly disagree and $5=$ strongly agree have been used. The data was collected from the construction experts in Selangor state of Malaysia. Random sampling technique is used to collect the data from 105 construction experts.

\section{Results and Discussion}

The questionnaire was distributed among construction professionals. The data collections record shows from a total of 105 questionnaires distributed among experts, 90 questionnaires were collected and 15 participants did not respond. The percentage of the returned data was shown $85.7 \%$ which indicate an acceptable rate of respond from the participants. Frequency, Reliability, Descriptive analysis and correlation tests were applied on the data. 


\subsection{Demographic Analysis}

The demographic analysis of the study as shown in the Table 1 indicates that male participants were larger than female and the maximum respondent age was 30-35 years. The study respondent's educational qualification has maintained significant impact on the findings where findings show that most of the respondents had diploma and bachelor degree of sciences and most of them were from engineering background and experience of the respondent's shows between 3-5 years.

\section{Table 1}

Demographic Analysis

\begin{tabular}{llcc}
\hline Description & Variables & Frequency & Percentage (\%) \\
\hline Gender & Male & 55 & 61.10 \\
& Female & 35 & 38.9 \\
& $20-25$ years & 8 & 8.9 \\
& $25-30$ & 26 & 28.9 \\
Respondents highest qualification & $30-35$ & 40 & 44.4 \\
& 40 and above & 16 & 17.8 \\
& SPM & 13 & 14 \\
Discipline of Expertise & Diploma & 26 & 28.9 \\
& Bachelor degree & 30 & 23.3 \\
& Master degree & 21 & 32.2 \\
& Engineer & 29 & 11.1 \\
& Architecture & 10 & 17.8 \\
Years of experience in construction & Quantity survey & 16 & 25.5 \\
& Contractor & 08 & 8.9 \\
& Developer & 23 & 4.4 \\
\hline N = 90 & others & 19 & 21.1 \\
& Less than 3 Years & 45 & 16.0
\end{tabular}

\subsection{Data Reliability}

Cronbach's coefficient alpha individually as shown in the Table 2 indicate that reason of changes in construction projects has alpha value of 0.73 , Risk management of changes yields a value of 0.83 , hindrances of apply risk management carries a value 0.843 . "Common types of changes" shows alpha value less than 0.7 followed by "measurement of changes" with a value of 0.566 , "cost management" with a value of 0.623 and "Assessment of Risk Impact of Changes" with a value of 0.504 . Overall, the reliability test indicate satisfactory results to continue the questionnaire where Cronbach coefficient alpha value is more or closer to the 0.70 .

Table 2

Cronbach's coefficient alpha Values

\begin{tabular}{lcc}
\hline Description & Cronbach's Alpha & N of Items \\
\hline Change Management & 0.68 & 7 \\
Reasons of change in construction Projects & 0.73 & 18 \\
Measurement of Changes & 0.623 & 4 \\
Cost Management & 0.566 & 4 \\
Methods of Weighting the quotation rates & 0.706 & 7 \\
Risk Management of changes & 0.873 & 15 \\
Assessment of Risk Impact of Changes & 0.504 & 8 \\
Hindrances of Applying Risk Management & 0.843 & 4 \\
\hline
\end{tabular}

\subsection{Descriptive statistics}

Table 3 shows the top rated variables which are discussed here. Most common changes as past studies also mentioned are design, contractor, and client's related changes. In the following part 
tendering on the basis of an incomplete design, which then changes during the course of the construction phase, budgeting, inadequate communication, unexpected ground conditions and client change the scope of the work are the key reasons of the changes. Through a paper based exercise of issuing site memorandums (SM), quoted rates (QR), variation orders (VO) and monthly payment certificates (MPC) are the most common methods of management. Proper planning and allocated role and responsibility of having good communication strategies are the key variables rated higher for manage risk in the construction project. Practicality of risk management and implementation of risk management applied to hindrance risk management in the construction projects.

\section{Table 3}

Descriptive Analysis of each part of the questionnaire and top rated variable

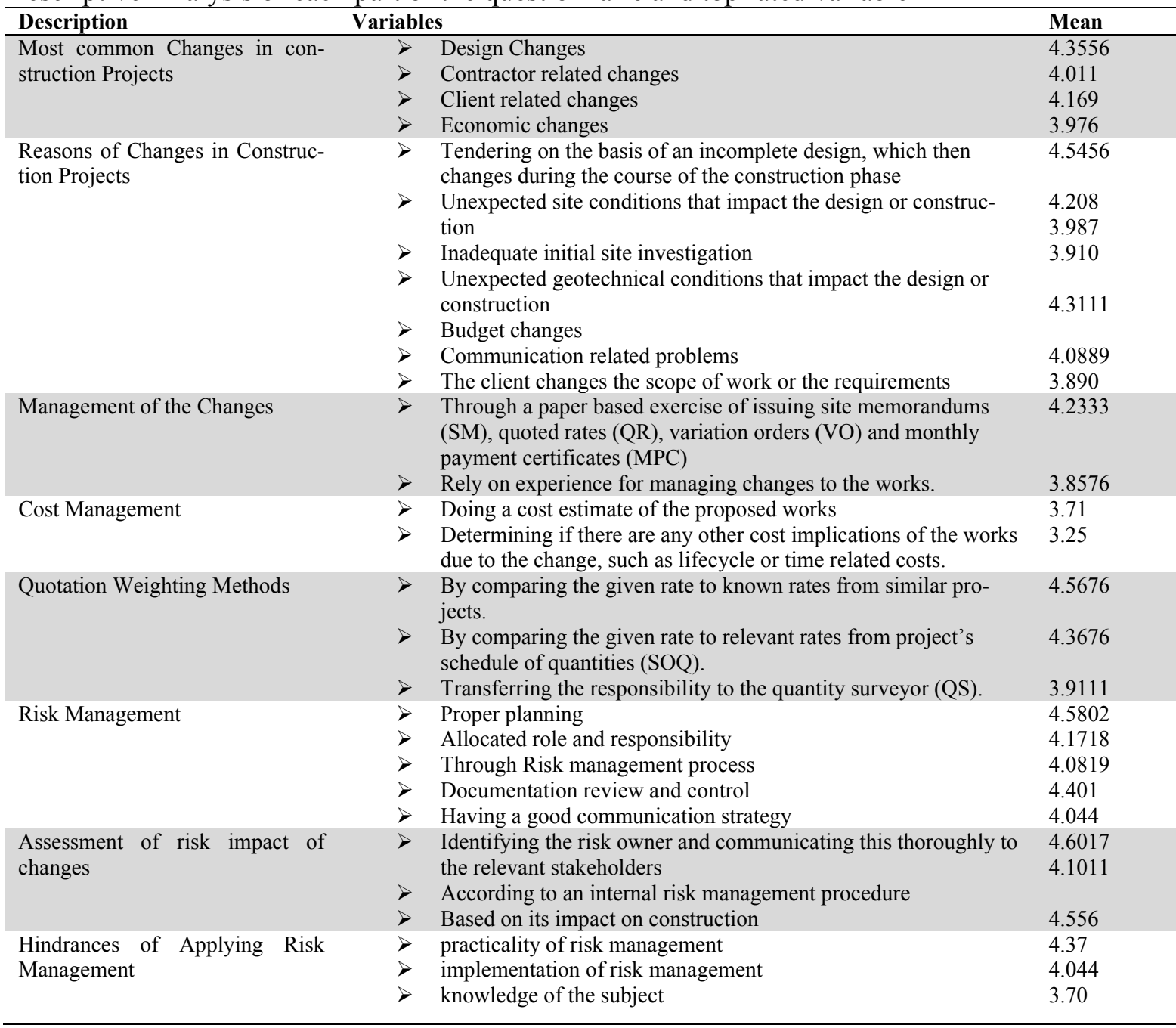

\subsection{Correlation of Change, Risk and Cost Management}

There is a significant relationship between the changes and the risk of increasing the cost of the construction projects (Williams, 1999; Park \& Peña-Mora, 2003). The correlation shown in Table 4 indicates a significant relationship among the factors of change leads to the risk of increasing cost of the construction project. The correlation between change management, cost management and risk management is interesting. It shows that there was a significance correlation among risk management, cost management and change management and the positive relationship of $51.1 \%$ means that as one variable goes up or down so will the other one. 
Table 4

Correlations among Risk, cost and Change Management

\begin{tabular}{llccc}
\hline & & risk management & costmanagement1 & change management \\
\hline \multirow{3}{*}{ Risk management } & Pearson Correlation & 1 & $.511^{* *}$ & $.511^{* * *}$ \\
& Sig. (2-tailed) & & .003 & .003 \\
& $\mathrm{~N}$ & 90 & 90 & 90 \\
\multirow{3}{*}{ Cost management1 } & Pearson Correlation & $.511^{* *}$ & 1 & $.000^{* *}$ \\
& Sig. (2-tailed) & .003 & 900 & 90 \\
\multirow{4}{*}{ Change management } & $\mathrm{N}$ & 90 & $1.000^{* *}$ & 1 \\
& Pearson Correlation & $.511^{* *}$ & .000 & 90 \\
\hline **. Correlation is significant at the & Sig. (2-tailed) & .003 & 90 &
\end{tabular}

\subsection{Discussion}

The objective of the study has been to learn how risk and cost managed in the change management based on theoretical and industrial practices. To obtain the objective the quantity survey has been conducted where questionnaire was designed in such a way to connect and identify change management in construction projects. The questionnaire was started with change management or common types of change management frequently happened in the construction industry where respondents were rated on Likert's scale five. The most common types of changes in construction projects have been identified as design changes, client, contractor and economic related changes. Questionnaire further identified the changes reason and about 18 different types of reasons have been surveyed among top reasons of changes. Unexpected geotechnical conditions that impact the design or construction, inadequate initial site investigation, flawed or impractical initial designs, impact of decisions or designs from the other disciplines collaborating on the project, impact of works by other contractors also working on the project, construction methodologies that change, client changes the scope of work or the requirement are among important factors for change management. Through a paper based exercise of issuing site memorandums (SM), quoted rates (QR), variation orders (VO) and monthly payment certificates (MPC) are the changes controlled or overlooked by the engineers on construction sites.

Performing a cost estimate of the proposed works is followed by determining whether there are any other cost implications of the works due to the change, such as lifecycle or time related costs, determining the effect of the work on the project budget and contingencies. Risk Management related factor rated top are proper planning followed by documentation review and control, allocated role and responsibility, through Risk management process and having a good communication strategy. So in the context it shows the proper planning may reduce risk and good management in the construction projects.

\section{Conclusion and recommendation}

The study has embarked that change management has significant impact on risk leading to the cost increment of the construction projects. The study has concluded that tendering on the basis of an incomplete design is the most topped reason of change demanding in the construction period followed by unexpected geological condition, budgeting and client change the scope. Thus in contrast proper planning and utilization of risk management process may reduce the risk of increasing cost. The study has also found client and contractor as the key players of the projects and any changes may lead to the higher risk of higher cost in the construction project. Implementation of risk management and knowledge of the subject is recommended to the project management to avoid changes as will hindrances the risk of cost and change management.

\section{Acknowledgement}

The authors would like to thank the anonymous referees for constructive comments on earlier version of this paper. 


\section{References}

Bakhary, N. A., Adnan, H., \& Ibrahim, A. (2015). A study of construction claim management problems in Malaysia. Procedia economics and finance, 23, 63-70.

Butt, A., Naaranoja, M., \& Savolainen, J. (2016). Project change stakeholder communication. International Journal of Project Management, 34(8), 1579-1595.

Clough, R. H., \& Sears, G. A. (1986). Construction contracting: Wiley New York. Google Scholar.

Cunningham, T. (2017). What Causes Cost Overruns on Building Projects?-An Overview.

Hanna, A. S., Thomas, G., \& Swanson, J. R. (2013). Construction risk identification and allocation: Cooperative approach. Journal of Construction Engineering and Management, 139(9), 10981107.

Hao, Q., Shen, W., Neelamkavil, J., \& Thomas, R. (2008). Change management in construction projects. Paper presented at the Proceedings of International conference on information technology in construction.

Ibbs, C. W., Kwak, Y. H., Ng, T., \& Odabasi, A. M. (2003). Project delivery systems and project change: Quantitative analysis. Journal of Construction Engineering and Management, 129(4), 382-387.

Lee, S., Peña-Mora, F., \& Park, M. (2005). Quality and change management model for large scale concurrent design and construction projects. Journal of Construction Engineering and Management, 131(8), 890-902.

Long, N. D., Ogunlana, S., Quang, T., \& Lam, K. C. (2004). Large construction projects in developing countries: a case study from Vietnam. International Journal of project management, 22(7), 553-561.

Mišić, S., \& Radujković, M. (2015). Critical drivers of megaprojects success and failure. Procedia Engineering, 122, 71-80.

Motawa, I., Anumba, C., Lee, S., \& Peña-Mora, F. (2007). An integrated system for change management in construction. Automation in Construction, 16(3), 368-377.

Murie, F. (2007). Building safety-An international perspective. International Journal of Occupational and Environmental Health, 13(1), 5-11.

Mushtaq Ahmad, A. M. J. A. T. (2018). Safety Management in Construction Projects: Malaysia Context. International Journal of Scientific \& Engineering Research, 9(2), 1597-1606.

Osipova, E. (2008). Risk management in construction projects: a comparative study of the different procurement options in Sweden. Luleå tekniska universitet.

Park, M., \& Peña-Mora, F. (2003). Dynamic change management for construction: introducing the change cycle into model-based project management. System Dynamics Review: The Journal of the System Dynamics Society, 19(3), 213-242.

Radujković, M., \& Sjekavica, M. (2017). Project management success factors. Procedia Engineering, 196, 607-615.

Sanchez, H., Robert, B., Bourgault, M., \& Pellerin, R. (2009). Risk management applied to projects, programs, and portfolios. International Journal of Managing Projects in Business, 2(1), 14-35.

Serrador, P., \& Turner, R. (2015). The relationship between project success and project efficiency. Project Management Journal, 46(1), 30-39.

Williams, T. M. (1999). The need for new paradigms for complex projects. International Journal of Project Management, 17(5), 269-273.

Winch, G. M. (2010). Managing construction projects. John Wiley \& Sons. Google Scholar

Yalegama, S., Chileshe, N., \& Ma, T. (2016). Critical success factors for community-driven development projects: A Sri Lankan community perspective. International Journal of Project Management, 34(4), 643-659.

Zhao, Z. Y., Lv, Q. L., Zuo, J., \& Zillante, G. (2009). Prediction system for change management in construction project. Journal of Construction Engineering and Management, 136(6), 659-669. 


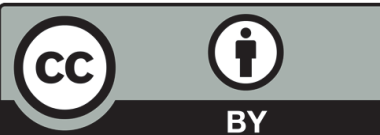

(C) 2019 by the authors; licensee Growing Science, Canada. This is an open access article distributed under the terms and conditions of the Creative Commons Attribution (CC-BY) license (http://creativecommons.org/licenses/by/4.0/). 